\title{
Shoulderpads and shagpile: architectural referencing in the television series Gloss
}

Linda Tyler, Centre for New Zealand Art Research and Discovery, National Institute of Creative Arts and Industries, University of Auckland, Auckland

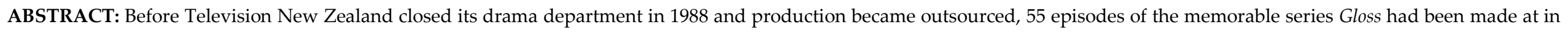

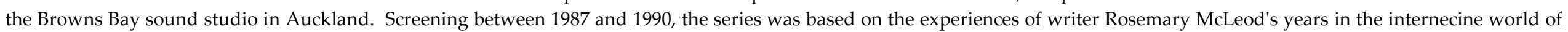

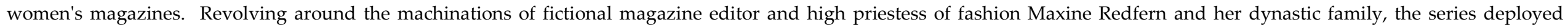

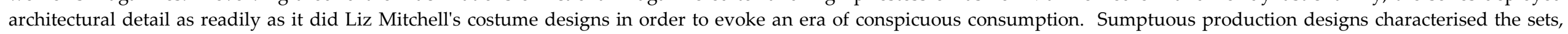

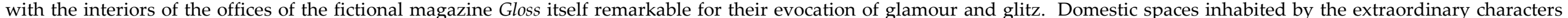

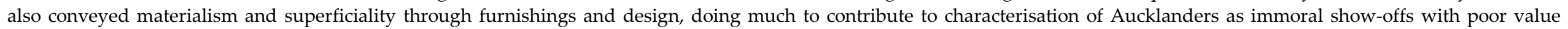

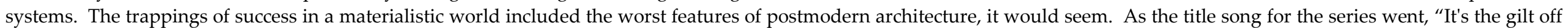

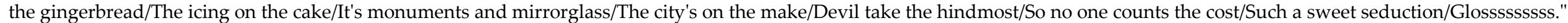

Screening on Wednesday nights on TV2 in the late 1980s, Gloss was New Zealand's first and last attempt at the "Dallasty" brand of glitter soap opera. While the programme in its entirety is paradigmatically postmodern in its use of parody and pastiche, the set design alone allows a case study of the archetypal 1980s interior in microcosm. In the homes and workplaces of the Redfern clan are found many features characteristic of this period in architecture, including the use of reflective surfaces and appropriation of design elements from the early twentieth century. Perhaps more than anywhere else, the use of postmodernist design in this particular local television series can be seen to operate symbolically, driven by the desire of the developers of this supersoap to show rather than tell a story.
Based on the real-life experiences of writer Rosemary McLeod, who had worked on the women's magazine Eve in the preceding decade, Gloss is best remembered for its haute couture styling, with fabulous hats and shoulderpadded suits paraded by the staff working in the fictional downtown office of the eponymous magazine. Added intrigue was provided by the machinations of the extended family of the magazine's editor, Maxine Redfern. These various backstabbings and doublecrossings were mostly carried out in the inner eastern and western suburbs of Ponsonby, St Mary's Bay and Remuera. Apart from the location shoots, the filming took place in Brown's Bay on Auckland's North Shore, a suburb otherwise only ever mentioned in the scripts in order to be derided. It was a very Auckland programme, and wore its prejudices proudly, in the same way that Metro magazine still unashamedly styles itself "the Auckland magazine." But, unlike Metro, the television programme Gloss was never intended to offer up any authenticity in its treatment of its subject

Metro's staff writer Richard Gordon was the first to critique the bias of the programme and to point up the ultimate irony of its creation: writer Rosemary McLeod lived, not in Mt Eden in Auckland, but Mt Victoria in Wellington. He implies an anti-Auckland agenda to the programme, in the lead-in to his article "Gloss Dross?" which appeared in the September issue of Metro in 1987 in response to the launch of the series in August of that year: 
After years of planning and much self-publicity, Television New Zealand presents Gloss, its crowning achievement for 1987. Gloss is the human story of life inside a women's magazine; the story of the lives and lusts of a group of people the rest of the country seems to believe can only be found in Auckland. It is written by a Wellingtonian. ${ }^{1}$

While it could be argued that Gloss did much to develop the popular view of Auckland as isolationist, and to build a characterisation of Aucklanders as immoral show-offs with dreadful value systems, by 1987 it could be argued that the concept of the JAFA was already rolling, and was knowingly capitalised on by Gloss's producer. In explaining her determination to keep the programme's setting as Auckland despite attempts to shift production to Lower Hutt's Avalon studios in 1988, producer Janice Finn mentioned her home town's legendary ostentatious display of wealth as her motivation: "I wanted to do it from the Queen City because it's such a greedy old town. People are brash about showing off their money."2

The point of difference from Close to Home (in which Janice Finn herself had starred) and the

${ }^{1}$ Gordon "Gloss Dross" p 55.

${ }^{2}$ Williamson "Gloss: light bright spite" p 17. other local television dramas that preceded it was that Gloss was aiming to be both ironic and international, conveying its position as much through its design and its scripts and characterisation. Producer Janice Finn recalls that:

[Rosemary McLeod] thought up Maxine and Magda, two characters very close to her heart ... and I wanted the rich family ... Both of us wanted a comic aspect, a kind of satire on the times ... It was very different to anything that had been done before because it was so frivolous. For the times it was bold and bit in your face. ${ }^{3}$

Diana Wichtel got the joke and previewed the programme approvingly in the New Zealand Listener:

Gloss is far from the social-disability-of-the-week style of series we've been used to. Instead of Maori land rights and sexual harassment, there will be lots of gorgeous bodies with matching faces, nice clothes, sex and money. It's about the Auckland where wealth, once discreetly deployed from behind high fences in the best suburbs, is having to move aside for the make-mineMercedes generation that grew up collecting share issues the way other kids collect first-day covers. Their motto: If you got it, flaunt it. If you haven't, get it. ${ }^{4}$

Given that not all viewers would be attuned to the risibility of this ideology of

${ }^{3}$ Ward "Gloss" n.p.

${ }^{4}$ Wichtel "High cheek and lip-lustre" p 21. consumption, attention was paid to showcasing New Zealand design and decorative art objects so that the series operated in a kind of double code. Programme developers quickly recognised that amongst its viewers there would be those who were attracted to the soapy plots, and those who relished the visual experience of a locally-made drama about beautiful people living glamorous lives in high fashion. Significantly, Gloss's debut coincided with the development of a system of analysing ratings which would soon revolutionise New Zealand television programming. ${ }^{5}$ As Paul Hunt points out "a new ability to break down ratings according to demographics revealed that Gloss was a hit with women and drew a cult following amongst young adults - a good result for advertisers." 6 Encouraged to see Gloss as good precisely because it was bad, by reviewers such as Wichtel, the programme

${ }^{5}$ Under the revised AGB McNair system, "teenagers" (15-24) were a separate demographic from "children" (514). Adult demographics, which had previously separated "men" and women in 25-39 and 40+ groups were now merged. Aside from the new 15-24s, key demographics from this point on were "All 25-39" and "All 25-54" and "All Household Shoppers." Further changes would occur after the arrival of "peoplemeter" technology in 1991.

${ }^{6}$ Ward "Gloss" n.p. 
quickly became appointment viewing amongst women of a certain age, while consistently repelling men over 40 . The high camp posturing of the characters was pitched to appeal to this female demographic (called the "household shoppers group" by advertisers) as were the clothes and interiors depicted.

Gloss fits the definition of a "supersoap," a term coined by Scottish television critic Richard Kilborn to distinguish the primetime series Dallas and Dynasty from their daytime relatives. The features that he identifies as characterising supersoaps can all be found in Gloss: the supremacy of personal over public worlds; an extended, dysfunctional family as the nucleus of the fictional community; threats to order arising within the family rather than externally to it and themes of wealth and greed, facilitated by the family's ultra-rich status. ${ }^{7}$ Gloss diligently followed this formula to maintain its entertainment value. As television historian Trisha Dunleavey observes,

Conceived in 1985-86, following a veritable colonisation of local primetime TV by Dallas, Dynasty, Knots Landing and Falcon Crest, Gloss was as much a tongue-in-cheek

${ }^{7}$ Kilborn Television Soaps p 30. response to this American "invasion" was it was a "Dallasty" clone. Gloss could afford to risk blending genre conformity with genre send-up because audiences knew the "Dallasty" conventions so well. By the time that Gloss appeared, most local viewers were acquainted with at least one of the above imports. ${ }^{8}$

Unlike the American prototypes such as ABC's Dynasty (itself a derivation of Dallas, the hit CBS prime time serial), Gloss had big stars with big hair, but a tiny budget for its production design. Janice Finn was heard to quip that what she had to work with wouldn't have kept Joan Collins in stockings for a month. In return for a big acknowledgement in the credits, dealers lent luxury cars and antiques, and fashionistas made hats and garments for minimal fees. Fifty-five 50minute episodes were made, with the last going to air early in 1990. Despite its short run, the afterlife of this local production has been enormous. It launched the careers of actors Miranda Harcourt and Lisa Chappell, boosted the profile of Auckland fashion designer Liz Mitchell, and gave interior designer Donald Grant Sunderland his first outing.

Conceived in 1985 by Finn (who came to be

${ }^{8}$ Dunleavy New Zealand Television Drama pp 382-383. known as "Gloss Boss"), Gloss was born of a time in which the local television industry and the economy - were at their most expansive:

When John [McRae, TVNZ head of drama] suggested he was looking for another series [after Finn's previous series The Seekers], I knew what I'd like to make, something a bit like Dynasty, something about the 80s and what was happening in Auckland ... wealth had changed and become very obvious. People were chucking money around and being very over-the-top in spending their dough. ${ }^{9}$

Gloss chronicled both the rise and fall of this ethos of rampant consumerism: It first went to air in August of 1987, just as the Dow-Jones Index peaked, before dropping $60 \%$ on 19 October that same year. Given this background of boom and bust, an element of nostalgia exists in the programme's presentation of profligate urban lifestyles. Trisha Dunleavy points out Gloss may have epitomised an era of conspicuous consumption but it also commemorated its end: "In concept and production values, it signified an excess that was no longer possible. $^{10}$

\footnotetext{
${ }^{9}$ Ward "Gloss" n.p.

${ }^{10}$ Dunleavy Ourselves in primetime p 199.
} 
Using his skills in deploying objects and furnishings to "show off money" while not actually spending much, was a major problem for Donald Grant Sunderland, the interior designer chosen to create the sets. Three main realms had to be depicted within the one sound stage: the domestic world which the fictional characters inhabited, the commercial world where they worked, and the leisure zone of the restaurant and bar where they entertained. In fitting out each interior, Sunderland was guided by not only the appropriation of motifs and historical references typical of the decade, but by the directive that the designs had to function symbolically. The interior sets were created before the exteriors were found, with Sunderland managing to squeeze seven sets into a studio the size of a local hall. These were itemised in a New Zealand Home and Building article written to promote the series to a readership interested in design:

A trendy-looking bar and restaurant known as $\mathrm{Al}^{\prime} \mathrm{s}$ Diner - a place where you gather to bitch and gossip; a grotty boarding house bedroom - the likes of which we have all seen at one time or another [inhabited by Miranda Harcourt's on-the-make character Gemma]; a high tech flat for Maxine; the Gloss open-plan office with its ever-so-quietly purring telephones and typewriters; and the Redfern mansion complete with living room, conservatory, grand staircase and upstairs bedroom. ${ }^{11}$

Examining each of these interiors in turn, it is possible to see how Sunderland used décor to both denote and depart from the 1980s convention for such environments. The downtown, off Queen Street offices of Gloss magazine are schemed in the decade's ubiquitous corporate colours of pink and grey, already synonymous with corporate culture by 1985 . This is a perfect pastel environment for the power-dressed editor to storm through in red, black and gold coats and extraordinary hats. (Ilona Rodgers' characterisation of Maxine Redfern now seems an eerie foreshadowing of Miranda Priestley, the role based on Vogue's editor Anna Wintour in the recent Hollywood film The Devil Wears Prada). Interviewed by Home and Building's writer, Sunderland explains the fit-out for the Gloss office, and his desire to have it seem "highly specced" with new technologies for the younger staff, featuring alongside the traditional tools for the older hacks such as Magda and Maxine. The journalists at Gloss are therefore shown working on golfball typewriters, while the screens of their new fangled desktop PCs remain dark and dot matrix printers silent,

${ }^{11}$ Williamson "Gloss: light bright spite" p 17. perched on escritoires still furnished with blotter pads and stationery compartments.

Matching the opening title sequence for the programme, the interior of the office makes a feature of the magazine's name, rendered in the ubiquitous architectural material of the period, mirror-glass. The title "Gloss," rendered in serif typography is displayed on a seamed and cushioned pink wall, illuminated by fluorescent tubing. Offering a palimpsest of the façades of many of Auckland's new office tower developments of the 1980s, the letters themselves have an appropriately reflective surface, exuding a superficial glamour and high finish, but also foreshadowing their own eventual deterioration. Just as patterns of repetition began to emerge in the cityscape of Auckland through the use of reflective finishes to maximise space and therefore rental returns, so this fictional office interior uses the same materials to connote superficiality. Two panels of translucent gridded glass bricks complement the play of mirrored glass as a visual illustration of the idea of "gloss" and several glass shelves and glass-topped tables are also deployed in this set as visual similes. Greedy for attention like the characters in the series, the gleaming word "Gloss" looms large 
behind the high front of the reception desk just as it does on the masthead of the magazine. Dominating and unambiguous, the artificiality of these reflective surfaces is accentuated by the sparing use of natural elements - a single potted palm - and all the mirroring provides a visual equivalent to the narcissism on display in the behaviour of the magazine's staff.

While horizontal surfaces in the office such as polished granite for benchtops and flooring are kept hard and reflective to suit this theme, the walls are clad in raw silk for a luxury effect. The stylishness of each space is announced by the oblique placement of a reproduction Wassily black leather armchair in both the outer office and Maxine's inner sanctum. With a spare chrome structure slung with leather upholstery, this chair was designed by Marcel Breuer in 1920 for the living room of Wassily Kandinsky's house at the Bauhaus and is synonymous with stylish modernity. The desk of the chief journalist Magda McGrath, displays the ultimate office accoutrement of the connected 1980s working woman, a filofax. Finlay Macdonald seized on this detail in his Listener preview of the second series, commenting "the setting of Gloss bears about as much resemblance to our northern conurbation as Maxine's rag does to a real magazine. And you still can't buy a filofax in Auckland."12 Thus the messages conveyed by the Gloss magazine interior (which is largely the preserve of women with a token male journo for light relief) is that working in a magazine office can be an aesthetic experience where the design elements are technologies of self fashioning.

Away from the office, clandestine personal and business meetings get conducted in Al's Diner, operated by Alistair Redfern, Maxine's conniving and venal son. His domain is decorated in an amalgam of chromium and neon which was rumoured to have been intended to be a hybrid of the café behind the mirrored façade of Chase Corporation's Mid City complex and the coffee cart operated by artist John Reynolds as "John's Diner" at the corner of Queen Street and Mayoral Drive. Described as "a trendy restaurant" and "a good place to be seen" with a "sleek chromed interior"13 in the publicity about the series, the set for Al's Diner aimed for fashionable sophistication with American inflections. The colour scheme for this interior was darker,

${ }^{12}$ Macdonald "Soaps: life as we show it" p 20.

${ }^{13}$ McCarthy "Gloss" pp 31-35. with purple walls, terracotta and Texas blue furnishings, including curved and cantilevered chrome bar stools topped by plastic tractor seats. Chromium-edged couches upholstered in vertical stripes surround glass top tables to create an effect reminiscent of plush hotel or transportation lounges of the 1950s. Indeed, the magazine description of this interior remarks on it having "the feeling of a railway carriage."14 These references are used to enhance the upwards mobility of the character Gemma who manages to inveigle Alistair into marriage and then plans her campaign for capturing the Redfern millions in this setting. While avoiding the unconventional shapes, bright colours and patterned surfaces of the Memphis Group, in the interior for Al's Diner Sunderland manages to use the Art Deco revivalism of the 1980s to parallel the aspirations of characters on the make.

A location in St Mary's Bay was chosen as the habitat for divorced editor and archetypal Cosmo girl, Maxine Redfern. Exterior establishing shots show it to be a white stuccoed multi-unit design, again with Art Deco references, while its interior is themed

${ }^{14}$ McCarthy "Gloss" p 34. 
around the ladderback design of a Charles Rennie Mackintosh chair. According to Sunderland, Maxine's apartment was meant to be contemporary in flavour to indicate "new money" and therefore to convey to viewers that Maxine was a self-made woman. There is even modern art on the walls in the form of some Rodney Fumpston prints. Grey, white and aqua are used here to contrast with the antique-laden interiors inhabited across town in Remuera by Maxine's reviled mother-inlaw, the matriarch Olivia Redfern. As the writer for Home and Building correctly notes:

Gloss is about money, Auckland money, old money and new. The old money is there to be seen in the Redfern mansion full of antiques, quality pieces and elegance. This taste is well-established and is accepted. There is no need to prove anything to anyone - one simply knows. ${ }^{15}$

A two-storeyed Edwardian mansion was found for the exterior shots, and in the design of the interior sets for this location, Sunderland used Italianate columns over the entranceways and around the alcove of the king-size bed to suggest establishment wealth. Like the classical order, when it is deployed for the façade of a nineteenth-century bank, these architectural forms trade on tradition to

\footnotetext{
${ }^{15}$ McCarthy "Gloss" p 33
}

connote dependability, as well as a certain sort of class.

Sunderland's skilful conjuring of symbolic environments with his sets for The Office, The Diner, The Apartment and The Mansion equate with success in a materialistic world but also manage to suggest that all that glisters is not gold. In this, the semantics of these interiors intentionally chimes in with the sentiments of the theme song for the programme, performed by Beaver Storm. Stephen McCurdy's lyrics refer to archetypal 1980s mirror-glass tower blocks as seductive but ultimately mirage-like. There is a warning against selling out implicit in the lyric "It's the gilt off the gingerbread/The icing on the cake/It's monuments and mirrorglass/The City's on the make/Devil take the hindmost/So no one counts the cost/Such a sweet seduction/Glossssss."16

So rather than celebrating the materialist lifestyle that it depicted, Gloss offers a critique, and the interiors work towards this end. The final set created for the series acts as a counterpoint to all others. It is the bedroom in the humble boarding house in Ponsonby

16 McCurdy "[Theme song from] Gloss." where Gemma and her boyfriend lodge on arrival in the big city. Despite having achieved connubial bliss, Gemma is oblivious to the charms of her rented accommodation. In the first scene using this set, she announces her intention to make it over just as she will be made over from small town ingénue to scheming fortune hunter. Like Cinderella or the Little Match Girl, Gemma is a stock character, so in the first episode of Gloss both her outfits and the set for her domestic environment need to show room for improvement. Like a chrysalis shell, they must suggest a temporary ugliness that will be quickly shed in pursuit of greater glamour.

Auckland-based critics soon distanced their city from the series, but seem confused in their repudiation. As the second series went to air, critic Finlay Macdonald's leader for his article in the Listener profiling the show was "Just how close to home is Gloss..."17 concluding that it was a parody of overseas models before briefly speculating whether Gloss could have happened without Roger Douglas. No one drew attention to the aesthetic qualities that set Gloss apart from American soaps produced for afternoon or early evening audiences, as

\footnotetext{
${ }_{17}^{17}$ Macdonald "Soaps: life as we show it" p 20.
} 
Australian cultural historian Ien Ang has done in her study of Dallas. Her argument that it is the higher production values that distinguish an $8.30 \mathrm{pm}$ timeslot from an earlier one is useful for a consideration of the design of the sets for Gloss. As Ang points out, the greater attention given to visualisation in Dallas created an important formal difference. Whereas in daytime soaps the visual element is kept to a minimum, in the mid-evening slot, visual attractiveness is driven by a desire to show rather than tell a story. ${ }^{18}$

Gloss was very different from any previous local series. It is worth remembering that it was devised for TV2 rather than TV One as part of a strategy to boost the channel's ratings with under 40s before TV3 arrived to entice these viewers away. ${ }^{19}$ As such, it was intended to be both chic and clever and to enhance the alternative channel identity. Rather than striving for authenticity in its depiction of New Zealand life, Gloss deployed irony, parody and humour in all aspects of its production. With the benefit of hindsight, the design used in this production can now be seen to exemplify some key aspects of the local take on postmodernism in the 1980s.

\footnotetext{
${ }^{18}$ Ang Watching Dallas p 62.

${ }^{19}$ Dunleavy New Zealand Television Drama p 380.
} 


\section{REFERENCES}

Ang, Ien Watching Dallas: soap opera and the melodramatic imagination London: Methuen, 1985.

Dunleavy, Trisha New Zealand Television Drama: the first thirty years 19601990, PhD thesis in Film, Television and Media Studies, The University of Auckland, 1999.

Dunleavy, Trisha Ourselves in primetime: a history of New Zealand television drama Auckland: Auckland University Press, 2005.

Gordon, Richard "Gloss Dross?" Metro (Auckland), (September 1987) 7(5):54-66

Kilborn, Richard Television Soaps London: Batsford Cultural Studies, 1992.

McCurdy, Stephen "[Theme song from] Gloss" Auckland: RCA Victor, 1987.

Macdonald, Finlay "Soaps: life as we show it" New Zealand Listener (June 1988) 121(2521):20-21

McCarthy, Lynne "Gloss" New Zealand Home and Building (August/September 1987): 31-35

Ward, Paul "Gloss: Television 1987-1990: A Perspective" NZ on Screen (22 September 2008); (retrieved 23 November 2009) http://www.nzonscreen.com/title/gloss-1987/background

Wichtel, Diana "High cheek and lip-lustre", New Zealand Listener (August 1987) 117(2477):21-22

Williamson, Lyn "Gloss: light bright spite" Onfilm (October 1987) 4(6):1718. 